Homepage: http://epubs.icar.org.in/ejournal/index.php/JWR

\title{
Status of vulnerability in wheat and barley producing states of India
}

\author{
Sendhil Ramadas, Ankita Jha, Anuj Kumar, Satyavir Singh and Ajit Singh Kharub \\ ICAR - Indian Institute of Wheat and Barley Research, Karnal, Haryana, India.
}

Article history: Received: 05-02-2017, Revised : 19-03-2017, Accepted: 02-05-2017

Citation: Sendhil R, A Jha, A Kumar, S Singh and AS Kharub. 2017. Status of vulnerability in wheat and barley producing states of India. Journal of Wheat Research 9(1): 60-63. doi.org/10.25174/2249-4065/2017/70082

*Corresponding author: r.sendhil@icar.gov.in

(C) Society for Advancement of Wheat and Barley Research

Global warming is unequivocal (IPCC, 2007) and developing countries are likely to be affected adversely by the impact of climate change (henceforth ' $\mathrm{CC}$ '). India being a sub-tropical country is highly prone to climatic variability and the anticipated changes will have significant impact on crop production since the crop yield levels are highly influenced by the prevailing weather conditions. Yield sensitivity to the anomalies of weather is an emerging issue in the perspective of climate smart farming particularly in the vulnerable regions and is expected to have a negative effect on the crop productivity, thereby, affecting the country's food production and supply (Sendhil et al., 2015; 2016). In the realm of foodgrains, wheat and barley, respectively the second and fourth largest cultivated cereals in the world, finds a significant part of production as well as consumption basket in India for food and nutrition security are highly vulnerable to $\mathrm{CC}$ and climate variability. The probable reason being the nutri-rich cereals are grown in Rabi, the season during which the increase in temperature is projected to be relatively higher than Kharif (Aggarwal, 2009; Mall et al., 2006). The two commodities altogether constitute for about 36 per cent share in the total food production of the country. India's geography, monsoon dependency and weather anomalies place wheat and barley production prospects and sustainability at crossroads across growing regions owing to its vulnerability. In the milieu, an attempt has been made in the present study to track the extent of vulnerability in wheat and barley producing states of India.
Sixteen wheat growing states having 99.39 per cent share in total production and ten barley cultivating states constituting 99.58 per cent share of national production were selected for analysing the vulnerability status. Vulnerability is the degree to which a region is susceptible to climatic risks and is determined by three factors viz., sensitivity (degree to which a region is affected by or responsive to climate stimuli), exposure (degree to which a region is exposed to frequent risks due to climate change) and adaptive capacity (ability of a region to better suit to the climatic stimuli or their impact). Vulnerability index (Vulnerability = Sensitivity + Exposure - Adaptive Capacity) for the selected states were computed following the approach of IPCC (2007). Secondary data on relevant indicators were sourced from official publications and reports from the Government of India. Under sensitivity, 15 variables; under exposure, 76 variables and under adaptive capacity, seven variables were considered to capture the vulnerability status. The collected data under each category were normalized to bring scale neutral for comparison based on the relationship (Table 1) with vulnerability (Kumar et al., 2016; Kale et al., 2016). After normalization, weights were assigned using the Principal Component Analysis (PCA) and the states were grouped into three vulnerable categories viz., high, moderate and low following Ayyoob et al. (2013) and Kale et al. (2016) approach. 
Table 1. Variables and their functional relationship with the vulnerability indicators

\begin{tabular}{|c|c|c|}
\hline Indicator & Variables & Relationship \\
\hline \multirow{15}{*}{ Sensitivity } & Area (TE 2015-16) & Negative \\
\hline & Production (TE 2015-16) & Negative \\
\hline & Yield (TE 2015-16) & Negative \\
\hline & $\%$ change in area (TE 2006-07 to TE 2015-16) & Positive \\
\hline & $\%$ change in production (TE $2006-07$ to TE $2015-16$ ) & Positive \\
\hline & $\%$ change in yield (TE 2006-07 to TE 2015-16) & Positive \\
\hline & CV for area (TE 2006-07 to TE 2015-16) & Positive \\
\hline & CV for production (TE 2006-07 to TE 2015-16) & Positive \\
\hline & CV for yield (TE 2006-07 to TE 2015-16) & Positive \\
\hline & Potential loss (TE 2006-07 to TE 2015-16) & Positive \\
\hline & Share in gross cropped area (TE 2015-16) & Negative \\
\hline & Groundwater level (2011) & Positive \\
\hline & $\%$ holdings of small and marginal farmers (2011 Census) & Positive \\
\hline & $\%$ area of small and marginal farmers (2011 Census) & Positive \\
\hline & Farmer suicide (QE 2015-16) & Positive \\
\hline \multirow{4}{*}{ Exposure } & $\begin{array}{l}\text { Month wise variation for weather variables (TE 2015-16) like temperature, relative } \\
\text { humidity, wind speed and rainfall during the Rabi months (November-April) }\end{array}$ & Positive \\
\hline & $\begin{array}{l}\text { Mean values for weather variables (TE 2015-16) like temperature, relative humidity, } \\
\text { wind speed and rainfall during the Rabi months (November-April) }\end{array}$ & Positive \\
\hline & $\begin{array}{l}\text { Month wise trend (1951-2010) for variables like temperature (maximum, minimum } \\
\text { and diurnal) and rainfall, relative humidity during the Rabi months (November-April) }\end{array}$ & Positive \\
\hline & $\begin{array}{l}\text { Long-run trend (1951-2010) for variables like temperature (maximum, minimum and } \\
\text { diurnal) and rainfall, relative humidity during the Rabi months (November-April) }\end{array}$ & Positive \\
\hline \multirow{7}{*}{$\begin{array}{l}\text { Adaptive } \\
\text { Capacity }\end{array}$} & Rural literacy rate (2011 Census) & Positive \\
\hline & Area under irrigation (2013-14) & Positive \\
\hline & Net income (TE 2015-16) & Positive \\
\hline & $\%$ of rural population below poverty line (2011 Census) & Negative \\
\hline & Average farm size (2011 Census) & Negative \\
\hline & Agricultural GDP share (TE 2015-16) & Positive \\
\hline & Farmers enrolled in weather based crop insurance (6 years average ending 2015-16) & Positive \\
\hline
\end{tabular}

Note: TE refers to triennium ending and $\mathrm{QE}$ refers to quinquennial ending

Analysis on vulnerability for wheat indicated that Jharkhand is highly sensitive (0.61) while Punjab registered the lowest sensitivity (0.18). Considering the exposure of regions to various climatic and weather variables during the Rabi season, it was found that Jharkhand had the highest exposure (0.48), whereas Punjab had the lowest (0.30). However, the magnitude of variation across states in climatic exposure is almost same. In terms of adaptive capacity, it was found that Maharashtra (0.63) had the highest adaptation, followed by Haryana (0.61) and Punjab (0.58). On the contrary, Jharkhand had the lowest adaptive capacity (0.21). Overall, the analysis indicated that Jharkhand is the most vulnerable region in terms of wheat production (Table 2) with an index of 0.88 and Punjab is the least vulnerable region (-0.09). Further, in wheat production, five states were classified as highly vulnerable, six states under moderate and five under less vulnerable.
High vulnerability is a consequence of being exposed and sensitive to the effects of CC coupled with limited adaptive capacity. Similarly, less vulnerable regions indicate that they are less exposed and sensitive but with strong adaptive capacity (Smit et al., 1999; Smit and Wandel, 2006).

In the case of barley, Madhya Pradesh registered the highest sensitivity (0.65), followed by Chhattisgarh (0.64) and Himachal Pradesh (0.56) while Punjab registered the lowest sensitivity (0.33). Considering the exposure of regions to various climatic and weather variables, it was found that West Bengal had the highest exposure (0.53) while Punjab had the lowest (0.31). In terms of adaptive capacity, it was found that West Bengal (0.59) had the highest adaptation index, followed by Uttar Pradesh (0.56) and Rajasthan (0.55). On the contrary, Madhya Pradesh and Chhattisgarh had the lowest adaptive capacity (0.28). 
Table 2. Vulnerability indices for wheat

\begin{tabular}{lccccl}
\hline \multirow{2}{*}{ State } & $\begin{array}{c}\text { Sensitivity } \\
\text { Index }\end{array}$ & $\begin{array}{c}\text { Exposure } \\
\text { Index }\end{array}$ & $\begin{array}{c}\text { Adaptive } \\
\text { Capacity Index }\end{array}$ & $\begin{array}{c}\text { Vulnerability } \\
\text { Index }\end{array}$ & $\begin{array}{c}\text { Vulnerabil- } \\
\text { ity Status }\end{array}$ \\
\cline { 2 - 5 } Assam & $\mathrm{A}$ & $\mathrm{B}$ & $\mathrm{C}$ & $\mathrm{A}+\mathrm{B}-\mathrm{C}$ & \\
Bihar & 0.47 & 0.45 & 0.24 & 0.68 & High \\
Chhattisgarh & 0.45 & 0.47 & 0.42 & 0.50 & Moderate \\
Gujarat & 0.54 & 0.41 & 0.25 & 0.70 & High \\
Haryana & 0.45 & 0.47 & 0.56 & 0.37 & Moderate \\
Himachal Pradesh & 0.32 & 0.34 & 0.61 & 0.05 & Low \\
Jharkhand & 0.45 & 0.44 & 0.48 & 0.40 & Moderate \\
Karnataka & 0.61 & 0.48 & 0.21 & 0.88 & High \\
Madhya Pradesh & 0.51 & 0.48 & 0.46 & 0.52 & Moderate \\
Maharashtra & 0.58 & 0.43 & 0.37 & 0.64 & High \\
Odisha & 0.55 & 0.47 & 0.63 & 0.38 & Moderate \\
Punjab & 0.57 & 0.46 & 0.33 & 0.70 & High \\
Rajasthan & 0.18 & 0.30 & 0.58 & -0.09 & Low \\
Uttar Pradesh & 0.35 & 0.41 & 0.54 & 0.21 & Low \\
Uttarakhand & 0.32 & 0.46 & 0.54 & 0.24 & Low \\
West Bengal & 0.42 & 0.38 & 0.51 & 0.29 & Low \\
\hline
\end{tabular}

In vulnerability analysis, adaptive capacity influences the region by modulating the exposure and sensitivity (Yohe and Tol, 2002; Gallopin, 2006; Adger et al., 2007). Overall, it was found that Madhya Pradesh (0.85) is the most vulnerable region in terms of barley production (Table 3) and Punjab (0.09) is the least vulnerable region. Among barley growing states, three were categorised as highly vulnerable, four under moderate category and three were found to be less vulnerable.

Preponderantly, wheat and barley production is a biological and societal activity which is guided by several factors including policies and weather aberrations across states (Ramdas et al., 2012). Hence, there are a lot of risks and uncertainties associated with farming leading to spatial vulnerability particularly for an agrarian economy like India which depends on monsoon. In the present study vulnerable regions for wheat and barley against climate change were identified and reported based on the composite index estimation viz., sensitivity, exposure and adaptive capacity. Relevant variables under each category were chosen with utmost care and the weights were assigned through PCA.

Vulnerability is the outcome of skewed production processes which is a result of less adaptive capacity relative to the potential impact (sensitivity + exposure). The investigation alarmed that the central part of India is highly prone to vagaries in climate change. High vulnerable states having a considerable share in crop production should be given prime priority in framing policies targeting for minimization of losses considering the adaptation strategies practiced in least vulnerable regions like Punjab and Haryana. The adaptive measures should be region and farm specific followed by appropriate implementation of policies and investment plans (Kumar et al., 2016). 
Table 3. Vulnerability indices for barley

\begin{tabular}{|c|c|c|c|c|c|}
\hline \multirow{2}{*}{ State } & $\begin{array}{l}\text { Sensitivity } \\
\text { Index }\end{array}$ & $\begin{array}{l}\text { Exposure } \\
\text { Index }\end{array}$ & $\begin{array}{c}\text { Adaptive } \\
\text { Capacity Index }\end{array}$ & $\begin{array}{l}\text { Vulnerability } \\
\text { Index }\end{array}$ & \multirow[t]{2}{*}{$\begin{array}{c}\text { Vulnerability } \\
\text { Status }\end{array}$} \\
\hline & A & B & $\mathrm{C}$ & $A+B-C$ & \\
\hline Bihar & 0.55 & 0.53 & 0.46 & 0.62 & High \\
\hline Chhattisgarh & 0.64 & 0.45 & 0.28 & 0.81 & High \\
\hline Haryana & 0.51 & 0.38 & 0.53 & 0.35 & Low \\
\hline Himachal Pradesh & 0.56 & 0.45 & 0.41 & 0.60 & Moderate \\
\hline Madhya Pradesh & 0.65 & 0.47 & 0.28 & 0.85 & High \\
\hline Punjab & 0.33 & 0.31 & 0.54 & 0.09 & Low \\
\hline Rajasthan & 0.41 & 0.44 & 0.55 & 0.30 & Low \\
\hline Uttar Pradesh & 0.51 & 0.52 & 0.56 & 0.46 & Moderate \\
\hline Uttarakhand & 0.44 & 0.39 & 0.44 & 0.39 & Moderate \\
\hline West Bengal & 0.53 & 0.53 & 0.59 & 0.46 & Moderate \\
\hline
\end{tabular}

\section{References}

1. Adger WN, S Agrawala, MMQ Mirza, C Conde, O'Brien K, J Pulhin, R Pulwarty, B Smit and K Takahashi. 2007. Assessment of adaptation practices, options, constraints and capacity. In ML Parry, OF Canziani, JP Palutikof, PJ van der Linden and CE Hanson, eds. Climate Change 2007: Impacts, Adaptation and Vulnerability. Contribution of Working Group II to the Fourth Assessment Report of the Intergovernmental Panel on Climate Change, pp. 717-743. Cambridge, UK, Cambridge University Press.

2. Aggarwal PK. 2003. Impact of climate change on Indian agriculture. Journal of Plant Biology 30(2): 189-198.

3. Aggarwal PK. 2009. Global climate change and Indian agriculture - Case studies from the ICAR network project, Indian Council of Agricultural Research, New Delhi.

4. Ayyoob KC, M Krishnadas and CMH Kaeel. 2013. Intra-regional disparities in agricultural development in Kerala. Agricultural Update 8:103-106

5. Gallopin GC. 2006. Linkages between vulnerability, resilience and adaptive capacity. Global Environmental Change 16:293-303.

6. IPCC. 2007. Climate Change 2007: Synthesis Report. Contribution of Working Groups I, II and III to the Fourth Assessment Report of the Intergovernmental Panel on Climate Change [Core Writing Team, Pachauri RK and Reisinger A (eds.)]. IPCC, Geneva,Switzerland, 104 pp.
7. Kale BR, K Ponnusamy, A K Chakravarty, R Sendhil and Asif Mohammad. 2016. Assessing resource and infrastructure disparities to strengthen Indian dairy sector, Indian Journal of Animal Sciences 86(6): 720-725.

8. Kumar S, A Raizada, H Biswas, S Srinivas and M Biswajit. 2016. Application of indicators for identifying climate change vulnerable areas in semiarid regions of India. Ecological Indicators 70: 507-517.

9. Mall RK, R Singh, A Gupta, G Srinivasan and LS Rathore. 2006. Impact of climate change on Indian agriculture: A review, Climatic Change 78: 445-478.

10. Sendil R, Randhir Singh and Indu Sharma. 2012. Exploring the performance of wheat production in India. Journal of Wheat Research 4(2): 37-44.

11. Sendhil R, P Ramasundaram, Raj Pal Meena, Thimmappa K and Indu Sharma. 2016. Tracking the yield sensitivity of rice-wheat system to weather anomalies. National Academy Science Letters 39(6): 401-405.

12. Smit B, I Burton, RJT Klein and R Street. 1999. The science of adaptation: A framework for assessment. Mitigation and Adaptation Strategies for Global Change 4:199-213.

13. Smit B and J Wandel. 2006. Adaptation, adaptive capacity and vulnerability. Global Environmental Change 16:228-292.

14. Yohe G and RSJ Tol. 2002. Indicators for social and economic coping capacity: Moving toward a working definition of adaptive capacity. Global Environmental Change 12: 25-40. 